\title{
Józef KOŻUCHOWSKI
}

Wyższe Seminarium Duchowne w Elblągu, Wyższa Szkoła Bankowa w Gdańsku

\section{Etyczne zobowiązania człowieka wobec świata zwierząt. Wizja Roberta Spaemanna}

Słowa kluczowe: etyka zwierząt, osoba, Spaemann, personalizm Key words: Animal ethics, person, Spaemann, Personalism

Świat zwierząt jako taki nie służy naszemu pożytkowi, lecz naszej radości. (Spaemann 2000: 465)

\section{Wstęp}

Znaczenie analiz z zakresu problematyki świata zwierzęcego w aspekcie filozoficzno-etycznym, mimo iż podejmowane jest od czasów filozofii starożytnej, nie przestało być doniosłe i aktualne (Ślipko 2009: 55-58). Takim się jawi z wielu względów, a m.in. z racji masowej i zarazem odrażającej metody hodowli zwierząt, niedostatecznego w dalszym ciągu postrzegania problemu ich cierpienia (którego jest zbyt dużo), przeprowadzania tego rodzaju eksperymentów na tych istotach, które muszą być uznane za zbyteczne (np. z uwagi na potrzeby przemysłu kosmetycznego), braku należytej troski o nie w krajach ubogich, wyniszczania na skutek ekspansjonistycznych dążeń gospodarczych i militarnych, jak nigdy dotąd na tak szeroką skalę gatunków zwierzęcych $^{1}$.

Z uwagi na powyższą sytuację Kościoły, jak podkreśla niemiecki profesor Ferdinand Krenzer, domagają się ochrony zagrożonych w swej egzystencji (na skutek faworyzowania interesów gospodarczych i militarnych) gatunków roślinnych i zwierzęcych, postrzegania w dużo większym stopniu problemu cierpienia zwie- 
Dociekania Spaemanna (respektowane niezależnie od wyznawanego światopoglądu i przynależności politycznej) już z tej racji są szczególnie cenne, ponieważ uwrażliwiają nas na powyższego typu sytuację zwierząt. Zarysowują zarazem sposoby rozwiązywania wszystkich najczęściej podejmowanych w dyskusjach etycznych zagadnień dotyczących naszego odniesienia do tych jestestw. Nie tylko zatem problemu hodowli, eksperymentów, cierpienia, wyniszczania gatunków, ale i statusu ontycznego zwierząt, ich tzw. praw, motywu ochrony, polowania, uboju, odpowiedzialności.

W rozważaniach niemieckiego myśliciela zwraca naszą uwagę to, że przypomina on i przywołuje jedno z zasadniczych pojęć Arystotelesowskiej filozofii, a mianowicie pojęcie życia. Na tej podstawie - wbrew upowszechnionemu stanowisku nowożytnej filozofii, zainicjowanemu i wyartykułowanemu przez Kartezjusza, (zgodnie, z którym zwierzęta jako pozbawione duszy przynależą do świata materii), podkreśla, że zwierzę nie jest rzeczą, lecz istotą żyjącą, objawiającą celowe dążenia i podobnie jak człowiek posiadającą wnętrze okryte tajemnicą (Tomasz z Akwinu 1985: 55)

Jednocześnie $\mathrm{w}$ przeciwieństwie do teorii antropologiczno-etycznych wykluczających czy też podważających istnienie jakościowej różnicy pomiędzy światem ludzkim a zwierzęcym, Spaemann oryginalnie uzasadnia, że człowiek istotowo przewyższa zwierzę. Cechuje go bowiem i wyróżnia zdolność do samorelatywizacji (umiejętności stawiania w centrum nie swojej, lecz drugiej istoty), jakiej zwierzę absolutnie nie przejawia.

Zainteresować nas musi również oryginalnie sformułowana przez niemieckiego filozofa argumentacja na rzecz ochrony zwierząt. Nie interes człowieka i jego potrzeby inspirują tę ochronę, gdyż ma ona swe zasadnicze źródło w godności ludzkiej (Spaemann 1993: 154).

Dwa podstawowe źródła złożyły się na prezentację poniższych rozważań: publikacje niemieckiego filozofa (książki i artykuły) oraz liczne wywiady przeprowadzone $\mathrm{z}$ nim przez autora artykułu w lutym i mar-

rząt, zakazu masowej ich hodowli, zaprzestania na nich eksperymentów, wykorzystywanych do produkcji kosmetyków, papierosów, alkoholu, poszerzenia przestrzeni natury. (Krenzer 2000: 262-263). 
cu $2011^{2}$. Autor tych analiz pragnie też podkreślić, że zostały one zaakceptowane przez Spaemanna i uznane jako zgodne z jego zamysłem.

\section{Miejsce zwierząt w hierarchii bytów i ich specyfika}

Zwierzę w hierarchii bytowej zajmuje pozycję środkową i plasuje się ona pomiędzy jestestwami o strukturze materialnej i duchowej. Zwierzę nie jest ani rzeczą, ani osobą, lecz istotą żyjącą (Ingesiep et al. 2008:11). Owszem, istnieje pewne zróżnicowanie wśród zwierząt, które pozwala mówić o hierarchii wśród tych istot żywych. Inne miejsce w niej przynależy, np. małpom, koniom, psom, słoniom jako tzw. wyższym zwierzętom, aniżeli dżdżownicom i myszom (Ingesiep, Baranzke, 2008: 79; wywiad, styczeń 2011) Zasadniczo jednak hierarchia wewnątrz istot żyjących, $\mathrm{z}$ racji tego, że jest ona trójstopniowa, przedstawia się następująco: najpierw ludzie, potem zwierzęta i wreszcie rośliny (Krąpiec 1996: 253, wywiad, luty 2011).

Chcąc odpowiedzieć na pytanie, jaka jest natura zwierzęcia z punktu widzenia metafizyki, trzeba stwierdzić, że jest ona zmysłowa (Gilson 1996: 298; wywiad, styczeń 2011). Wyróżnia go bowiem od roślin i stanowi o tożsamości to, iż ma duszę zmysłową ${ }^{3}$.

Przybliżając zaś specyfikę zwierzęcia w języku empirycznym, trzeba wskazać na jego uzdolnienia do percepcji o charakterze zmysłowym. Wśród tych ostatnich należy wymienić zwłaszcza dwa najważniejsze: do spostrzegania oraz do odczuwania (doznawania) z przyjemnością i bólem (Spaemann 1993: 154, wywiad, luty 2011) ${ }^{4}$.

2 Treści wywiadów, zarejestrowane na kasetach magnetofonowych i utrwalone na piśmie komputerowym, są w posiadaniu autora artykułu.

3 Wprawdzie, jak podkreśla filozof francuski, zwierzę jako istota czysto zmysłowa pozbawiona jest rozumu, posiada natomiast coś w rodzaju naturalnej roztropności i instynktownego sądu, co stanowi pewien stopień uczestnictwa w ludzkim rozumie. (Gilson 1996: 298). Jak konstatuje Arystoteles zwierzęta, podobnie jak rośliny, posiadają duszę wegetatywną. Jednak dopiero dzięki duszy zmysłowej są zwierzętami (Arystoteles 1995: 736b).

4 Jak podkreśla Arystoteles - ,Jestestwo, które ma zmysł, doznaje także przyjemności i bólu, a konsekwentnie rozeznaje przedmioty, które przynoszą przyjemność i zadają ból" (Arystoteles 1972: 414b). 
Przyjemność i ból są właściwościami i stanami zawierającymi w sobie ukierunkowanie i tzw. wektor. Ból zatem u istoty nań wrażliwej determinuje jej zachowanie zmierzające do uwolnienia się od tego przykrego doznania. Dlatego nie wolno bez poważnej przyczyny zadawać zwierzętom tego bólu, zwłaszcza silnego (wywiad, luty 2011).

Jak już stwierdzono, zwierzę jest istotą żyjącą. Jak każdy byt tego rodzaju jest nośnikiem sfery wewnętrznej, której istnienie możliwe jest do udowodnienia. Zwierzę przecież żywi życzenia, przeżywa różnoraki ból, wyraża swą radość, objawia lęk, itd. Na mocy tego faktu nie okazuje się rzeczą. Staje się tu zrozumiałe, dlaczego budzi sympatię i podobać się musi zwyczaj czy też praktyka, zgodnie, z którą każde zwierzę nawet w obrębie licznej trzody ma własne imię, a jego właściciel zwraca się doń osobiście. Niczego innego nie wyraża ona aniżeli trafnego postrzeżenia, czym jest zwierzę. Nie redukuje się ono do rangi rzeczy; jawi się jako indywiduum. Dlatego jeden ze znanych Spaemannowi francuskich pasterzy- roztaczających swą opiekę nad liczną trzodą owiec mógł rzec w swej ujmującej nasze serca wypowiedzi: nie chcę mieć więcej owiec aniżeli te, które znam $z$ imienia ${ }^{5}$.

Zwierzę ujawnia życie wewnętrzne, będące manifestacją duszy zmysłowej. Zgodnie $z$ trafnym stwierdzeniem Thomasa Nagela nigdy nie będziemy wiedzieli jak to jest być nietoperzem ${ }^{6}$. Podobnie nie dowiemy się, co znaczy być każdym innym zwierzęciem (np. kotem). Wszak widzimy, że dane zwierzę np. kot, nie jest tylko przedmiotem, który widzimy, lecz, że i on nas widzi, i że za tym spojrzeniem kryje się na zawsze ukryta tajemnica, która jedynie daje o sobie znać w tym spojrzeniu (Spaemann 2000: 472). Nie potrafimy bowiem wniknąć w uczucia zwierzęcia, które $\mathrm{z}$ tego tytułu pozostanie dla nas zawsze zagadką (Kożuchowski 2006: 90; wywiad, luty 2011). Z tej racji

5 Przytaczając powyższą opinię, równocześnie Spaemann chwali zwyczaj, jaki istniał dawniej u chłopów, który kazał im zwracać się po imieniu do każdego ze zwierząt. (Wywiad, luty 2011).

6 Podobne stanowisko zajmuje jeden z najwybitniejszych współczesnych antropologów niemieckich Helmuth Plessner, gdyż - jak podkreśla - „Nigdy nie możemy wiedzieć, co naprawdę czuje zwierzę, co przeżywa jako motyw, a co jako bodziec, gdy zachowuje się w określony sposób.” (Plessner 1988: 232). 
kard. John Newman mógł powiedzieć, że anioł jest dla nas bardziej zrozumiały aniżeli zwierzę. Aniołowie są istotami rozumnymi i dlatego na gruncie myślenia oraz rozumu możemy porozumieć się z nimi lub przynajmniej wyobrazić sobie, co znaczy być aniołem. Zwierzęta natomiast mają właściwą dla siebie subiektywność, (czyli nie są przedmiotami i trzeba widzieć u nich wnętrze, skoro przeżywają różnorakie stany psychiczne), która będzie dla nas zawsze zakryta (Kożuchowski 2006: 90; wywiad, luty 2011).

Z uwagi na powyższy fakt głęboki sens ujawniają zaskakujące dla nas zachowania względem nich $w$ archaicznych kulturach łowieckich, w rodzaju np. gestu prośby o przebaczenie. Wszak dokonuje się w nich symboliczne uznanie, że byt zwierzęcia jest, by tak rzec, wsobny Selbstsein.

Ze zwierzętami rozmawiamy również w naszym języku, tzn. takim, którego gramatyka nie jest dostępna dla nich. W wyniku jednak takiego odniesienia zbliżamy się bardziej do prawdy aniżeli ci, którzy traktują je jak przedmioty (Spaemann 1993: 229).

Naturalnie, istnieje niesprowadzalna istotna różnica pomiędzy człowiekiem a zwierzęciem. Z punktu widzenia ontologicznego odróżnia zwierzę od istoty ludzkiej to, że jest ono pozbawione duszy duchowej (Gilson 1960: 298; wywiad, luty 2011).

Natomiast w swych rozważaniach Spaemann akcentuje, że niższość zwierzęcia w stosunku do ludzi zaznacza się na dwa sposoby.

Człowiek bowiem przewyższa zwierzęta po pierwsze, inteligencją oraz zdolnością uwolnienia się od nacisku instynktów. Ta ostatnia umiejętność świadczy, że my jako ludzie pod wieloma względami okazujemy się wolni, czego nie można powiedzieć o istotach zmysłowych. Potrafimy przecież przez całe lata zdystansować się w stosunku do wartości użytecznych, dziedziny pożądania, potrzeby jedzenia i picia i nie kierować się przymusem w dziedzinie seksualnej, któremu podlegają zwierzęta, co konstatujemy na przykładzie zachowań w okresie rui. Drugi rodzaj przewagi człowieka nad zwierzętami jawi się jako uzdolnienie do relatywizacji własnego punktu widzenia, czyli jako umiejętność stawiania $\mathrm{w}$ centrum odniesień i zainteresowań nie siebie, lecz drugiej istoty (Spaemann 2000: 471). Mówiąc językiem 
Plessnera, oznacza ona charakterystyczny ludzki sposób bycia w świecie, którą określa jako ekscentryczną pozycjonalność (Plessner 1988: 240). Przejawia się zaś ta umiejętność m.in. w rezygnacji z dążenia do czegoś korzystnego, (na czym nam bardzo zależy), tylko dlatego, że przyniosłoby szkodę lub zadało ból innej istocie. Zwierzę, np. kot, nie zdobyłby się na taki akt - nie wie bowiem jak czuje się mysz, z którą się bawi (Spaemann 2000: 471) ${ }^{7}$.

\section{Czy zwierzęta mają prawa? Obowiązki wobec zwierząt}

Na gruncie tzw. ekologicznych teorii usiłuje się dowieść, że nie tylko człowiekowi, ale również zwierzętom przysługuje status moralny i prawa (Ingesiep, Baranzke 2008: 79-81; Vardy, Grosch 1995: 192-193; Czarnecki 2008: 217). Spaemann potwierdza, że współcześni rzecznicy tego poglądu niczego nowego nie mówią o uzdolnieniach zwierząt niż św. Tomasz z Akwinu, jeśli jako charakterystyczne wymieniają: doznania uczuciowe, wrażliwość na ból i cierpienie, swoistą celowość zachowa (Tomasz z Akwinu 1998: 292-302; Ślipko 2009: 68; wywiad, marzec 2011). Ich punkt widzenia w kwestii praw zwierzęcych uznać trzeba jednak za nieporozumienie ${ }^{8}$. Choć nie z tego powodu, że nie można wykazać u istot określanych zmysłowymi, rozumności choćby w elementarnym znaczeniu. Zachowania zwierząt wyższych i ich umiejętności wskazują, że dysponują one czymś, co można nazwać inteligencja praktyczną. Rozwiązują problemy, potrafią wybrnąć z trudnej sytuacji. Natomiast nie posiadają rozumu w sensie samoświadomości oraz nie wykazują się myśleniem niezależnym od danych okoliczności. „Myślą” więc tylko w powiązaniu $\mathrm{z}$ sytuacją i nie są $\mathrm{w}$ stanie, podobnie jak my, zdobyć się

Jak jednocześnie zaznacza Plessner: „Kiedy powstaje chaos, podczas wybuchu paniki, w ekstremalnych sytuacjach społecznych pojawiają się reakcje płynące z wzajemnego emocjonalnego pobudzenia, reakcje, które nie różnią się od zwierzęcych” (Plessner 1998: 238).

8 Jawi się on takim m.in., ponieważ wyklucza nasze naturalne prawo zabicia zwierzęcia nawet z uzasadnionej przyczyny. Zresztą nie sam fakt pozbawienia zwierzęcia życia stanowi problem, lecz tylko sposób, w jaki się odnosimy się do tej istoty. 
na dystans w stosunku do rzeczywistości oraz poczynić refleksję (wywiad, marzec 2011). Trzeba bowiem podkreślić, że relacje o charakterze praw występują tylko wśród istot będących osobami i obdarzonych samoświadomością. Zwierzęta zatem nie mogą być podmiotem prawa. Nie będąc zdolnymi do refleksji nie mają one jego świadomości. Konsekwentnie do tego faktu nie potrafią rozróżniać pomiędzy wymogami uprawnionymi i nieuprawnionymi. I nie sposób wyjaśnić tym istotom np. w przypadku zadania im bólu, w jakim celu się to uczyniło. Z powyższej racji nie można ich obciążać wymaganiami w sensie, w jakim czynią to ludzie. Ci ostatni stawiają te wymagania, oczekując, że zostaną przez drugich ludzi zaakceptowane (Spaemann 2000: 471) ${ }^{9}$.

Zwierzęta są całkowicie zdane na otoczenie, ponieważ nawet nie potrafią wyobrazić sobie pojęcia praw. Można więc powiedzieć, że zupełnie obojętna musi być dla nich kwestia bycia podmiotem prawa i w ogóle nie może ich ona interesować. To potwierdza, że nie mogą wchodzić w relacje o charakterze prawa.

Problematyka praw i obowiązków nie jawi się wprawdzie jako symetryczna. Nie można wyrazić się w ten sposób: ponieważ zwierzęta mają prawa, dlatego my mamy obowiązki. Należy bowiem sądzić tak oto: zwierzęta nie posiadają żadnych praw, ale my nie jesteśmy zwolnieni od powinności w stosunku do nich.

$\mathrm{Na}$ nas ciążą bowiem obowiązki względem powyższych istot. Człowiek winien strzec ich dobra, ponieważ jest osobą, wykazuje uzdolnienie do samorelatywizacji własnego odniesienia, czyli postawienia w centrum uwagi nie siebie, lecz drugie jestestwo (Spaemann 1993: 470-472). Ma on zatem oddalać od zwierząt wszelkie zagrożenia nie dlatego, że mają one prawa. Takie zachowanie wynika bowiem z jego godności i przynależy do niej. Potwierdza ją tylko, jeśli troską swą ogarnia istoty niżej odeń stojące, ponieważ uzdolnienie do niej ma swe źródło właśnie w godności. Skoro, jak mówi Pismo Święte, otrzymał władzę nad naturą, wtedy jego zwierzchnictwo ujawniać się winno nie jako panowanie tyrana, lecz króla wypełniającego swe obowiązki wobec zwierząt

9 Zwierzę nie jest również dlatego zdolne podjąć się obowiązków, ponieważ nie potrafi wyjść ze swej centryczności, (czyli stawiania siebie a nie drugiej istoty w centrum zainteresowań). (Spaemann 1993: 155). 
z tytułu własnej godności. Fakt ten zatem rzeczywiście go zobowiązuje i nie wolno mu samowolnie traktować istoty od siebie niżej stojącej.

Niestety, często ludzie błędnie rozumieją powyższe zagadnienie. $\mathrm{Z}$ tej racji, że zwierzętom nie przypadają w udziale prawa, sądzą, iż można z nimi obchodzić się tak, jak się chce. Jednakże nie sposób zgodzić się z takim zapatrywaniem. My ponosimy odpowiedzialność za te jestestwa, zwłaszcza te, które oswoiliśmy i podlegają naszej pieczy (Spaemann 1993: 230-232; wywiad, luty 2011).

\section{Eksperymenty na zwierzętach}

Następujące rzeczy należy uwzględniać przy tego rodzaju doświadczeniach.

Owszem, interesy medyczne usprawiedliwiają bólosprawcze eksperymenty na zwierzętach, ale dlatego, że zmierzają do ratowania ludzkiego życia, albo uniknięcia cierpienia. Z uwagi na dobro człowieka przeprowadza się przecież u niego operacje połączone z bólem. Można więc ze względu na jego pożytek poddawać operacjom zwierzęta, lecz przy użyciu narkozy, by nie zadawać im bólu nie do wytrzymania.

Zrozumiałe i uprawnione są również doświadczenia na tych istotach mające bezpośrednią wartość dla postępu naukowego i medycznego, a cierpienia zadawane $w$ ich trakcie, nie okazują się zbyt silne. Nad sprawą tą roztaczają swą pieczę komisje etyczne, ingerujące w procedury eksperymentów (np. z małpami) i czuwające nad tym, by nie przekraczano dozwolonych granic oraz nie działano wbrew naturze zwierzęcia (Spaemann 2000: 474; wywiad, luty 2011).

Za niedopuszczalne natomiast należy uznać eksperymenty na zwierzętach realizowane ze względu na potrzeby przemysłu kosmetycznego. Zwróćmy uwagę, jakie dyktują one odniesienia do tych istot, np. do zajęcy. Otóż wlewa się do ich oczu określone krople i sprawdza czy oczy te nie zostaną zupełnie zniszczone czy też doznają wyłącznie bólu i cierpienia. Zdecydowane „nie” dla tych praktyk jest tym bardziej uzasadnione, że mamy wystarczającą ilość produktów kosmetycznych, zapewniających upiększenie oczu kobiet i nie ma żadnej potrzeby wytwarzania kolejnych ich rodzajów. Nie musi się zaspaka- 
jać gustów nowej mody dotyczącej estetyki organów zmysłu wzro$\mathrm{ku}$, skoro za swą cenę ma zbędny koszmar cierpienia bezbronnych istot (oślepianie zajęcy) (Spaemann 2000: 473; wywiad, styczeń 2011; Vardy, Grosch, 1995: 192-193).

Wyklucza się także eksperymenty zmierzające do wykazania, że określone używki (np. wyroby tytoniowe) są nieszkodliwe i dostarczają samej przyjemności. Wszakże płacenie ciężkim cierpieniem zwierząt za tego typu przyjemności (o osiąganiu, której upewnić miały owe eksperymenty) sprzeciwia się godności człowieka. Istnieje wskazówka potwierdzająca, że tak właśnie rzecz się ma. Jest nią sposób i odcień reakcji na samą myśl o uzyskiwanej ewentualnie tą drogą przyjemności. Otóż każdy normalnie wrażliwy człowiek uznałby ją jako zatrutą, gdyby tylko dostrzegł, jakie konsekwencje sprowadza delektowanie się nią. Przyjemność ta byłaby więc możliwa tylko w przypadku ukrywania jej ceny.

Wraz z powyższego rodzaju eksperymentami należy podjąć wszelkie wysiłki zmierzające do znalezienia dróg zastępczych, do których zaliczyć wolno, np. testowanie na lekach, świeżym i jakby jeszcze żywym mięsie zwierząt, jako że bezpośrednio po ich zabiciu, oraz wszelkie inne możliwe działania, nie powodujące cierpienia tych istot (Spaemann 2000: 474-475; wywiad, luty 2011). Stosownie do wyników badań psychologicznych i socjologicznych okazuje się, że wysiłki tego typu nie podejmuje się w wystarczającej mierze, jeśli przedsiębrana praktyka nie jest wyraźnie ukazywana jako przejściowo tolerowane prowizorium. Dopóki bowiem wznosi się jeszcze nowe, wielkie instytuty i inne budowle oraz ustanawia miejsca pracy służące wyłącznie eksperymentom na zwierzętach, tak długo będą one pozyskiwane do tych eksperymentów jako ich ofiary (Spaemann 2000: 474). Należy zatem, według Spaemanna, dokonać znacznej redukcji instytucji zajmujących się prowadzeniem eksperymentów naukowych nad zwierzętami (wywiad, luty 2011). Wszelkie bowiem środki, utrwalające takie praktyki, są nie do pogodzenia z dalekosiężnym, zdecydowanym dążeniem do ich eliminacji.

Trzeba wreszcie ustanowić nowe kryteria określające nieunikniony stopień cierpienia zwierząt, by (jak podkreśla Spaemann), ich by- 
cie, by tak rzec, tylko bólem, nie definiowało istotnej części ich życia. Doświadczenie cierpienia jest zawsze czymś subiektywnym i jawi się jako ciemna strona losu. Dlatego świadome jego powodowanie, niezależnie od korzyści, do jakich ma prowadzić, jest nie do pogodzenia z ideą godności człowieka (Spaemann 2000: 474).

\section{Kwestia polowania}

W etycznej dyskusji na temat zwierząt kolejny ważny aspekt stanowi kwestia polowania (Vardy 1995: 193). Jak przedstawia się jego etos, gdy podejmowane jest ono dla samej uciechy i rozrywki? Oczywiście, zabijanie dla samego zabijania, prezentowałoby się jako czynność bezsensowna i niemoralna. Jeśli natomiast jest to aktywność nieodzowna, wówczas nie ma nic złego w tym, że poluje się chętnie i z uczuciem przyjemności, wręcz pasji. Czymś niezrozumiałym byłoby bowiem okazywanie niezadowolenia i złego humoru z czynności, która z etycznego punktu widzenia ma swą rację bytu i uzasadnienie z czterech powodów. Jawi się zatem jako rzecz konieczna, gdy w lesie zamieszkuje zbyt wiele zwierząt (saren, jeleni, lisów itd.), których liczba musi zostać zredukowana ze względu na wyrządzane poważne szkody (pierwszy powód). Stanowi nieporównywalnie lepsze rozwiązanie aniżeli ubój (powód drugi). Sprawia, że nie staje się udziałem zwierząt przerażenie i dręczący lęk, jakiego doznają w rzeźni na widok zabijanych spośród swego gatunku istot żywych. Dodajmy, że już sam transport, np. koleją żelazną do powyższego miejsca wyzwala u nich wielki stres, gdyż wyczuwają jaki spotka ich los. Z tego też tytułu, za godną najwyższej pochwały, należy uznać stosowaną już przez niektórych chłopów niemieckich praktykę zabijania krów na pastwisku przy użyciu odpowiedniego aparatu, jako że zwierzęta nie zdołają się zorientować o zamiarze swych właścicieli. Właśnie polowanie należy przedkładać nad ubojem z następującego trzeciego jeszcze powodu. Ubój okazuje się czymś gorszym dla zwierzęcia, również w porównaniu do walki podczas korridy, jakkolwiek również ta ostatnia praktyka jest problematyczna. Zadaje mu bowiem prawdziwą udrękę. Akt ten oznacza długi proces uśmiercania zwierzęcia, w którym jego ból i cierpienie są zwielokrotnione 
tym, że jest ono całkowicie zdane na otoczenie i bezsilne. Rozpoczyna się zaś ów proces wraz z transportem do rzeźni w bardzo stłoczonych wagonach. Zwierzę boleśnie wyczuwa i doświadcza jego finał z chwilą, gdy znajdzie się w tym miejscu. Już na sam widok krwi reaguje przeraźliwym lękiem, popadając w panikę. Wprawdzie w korridzie również zostaje zabite. W walce tego typu czuje się jednak sobą, broni się, cieszy wolnością, mając swobodę ruchu (Spaemann 2001: 140; wywiad, luty 2011).

Polowanie w dalszym ciągu jest koniecznością z uwagi na interes człowiek, ponieważ dostarcza mu pożywienia (powód czwarty), a nawet jest warunkiem przeżycia (Vardy, Grosch 1995: 193; wywiad, luty 2011).

Wreszcie wskazać można na rzecz polowania, argument typu pragmatycznego. Otóż mięso pozyskiwane od zwierząt tą drogą jest smaczniejsze, aniżeli w wyniku uboju, gdyż wielki stres, jaki on powoduje odbija się negatywnie na jego jakości (wywiad, luty 2011).

\section{Problem hodowli a zjawisko wegetarianizmu}

Hodowla zwierząt zobowiązuje do tego, by zapewnić im odpowiednie do ich natury godziwe warunki życiowe. Zakłada to, że nie pozbawi się ich możliwości zaspokojenia elementarnych potrzeb. W rachubę wchodzi tu nie tylko karmienie właściwą paszą, ale również sposobność nieskrępowanego poruszania się, grzebania w ziemi, egzystowania nie w ciasnym, ciemnym, lecz dużym i jasnym pomieszczeniu. W hodowli należy uwzględniać interes zwierząt (tj. ich potrzeby i dążenia), a nie wyłącznie człowieka (wywiad, luty 2011; Ślipko 2009: 60). Tymczasem niektóre jej sposoby są bardziej okrutne aniżeli zakończenie życia byka podczas korridy (Spaemann 1993: 229). Dzieje się to między innymi wtedy, gdy powoduje się w zbyt szybkim tempie przyrost na wadze (do 400-500 kg w ciągu trzech miesięcy), okupiony niewyobrażalnie wielkim udręczeniem zwierząt ${ }^{10}$. Ma to miejsce również

10 Według profesora Berttholda Walda, w Ludinghauseen w wielkiej farmie, w której hoduje się cztery tysiące świń, w możliwie najbardziej ciasnym pomieszczeniu, którego nigdy nie mogą opuścić i zażyć ruchu, ponieważ każda z nich musi mieć taką wagę, po upływie 90 dni hodowli. 
np. tam, gdzie kury nie dysponują żadną wolnością ruchu, byczki hoduje się na płynnych pokarmach w pozycji leżącej, a cielęta nie karmi się naturalną, zieloną paszą, co osłabia je tak bardzo, że nie potrafią stać na własnych nogach. Jasna barwa mięsa tych zwierząt objawia chorobę, będącą następstwem sprzecznego z naturą żywienia (wywiad, luty 2011). Rozpowszechnioną współcześnie masową metodę hodowli nie inaczej więc należy nazwać, niż jako niegodziwą praktykę. Staje się więc zrozumiała moda na wegetarianizm. Nieraz ma on przecież za swe podłoże protest przeciw zaobserwowanym aktom dręczenia zwierząt. Oczywiście sam wegetarianizm nie zobowiązuje nas moralnie. Nie gwarantuje też bycia nieskazitelnym etycznie. Hitler, jak wiadomo był wegetarianinem. Wszakże wegetarianizm sam w sobie nie jest niczym złym. $Z$ tego też względu nie musimy być wegetarianami, lecz tylko możemy nimi być, jeśli chcemy (Spaemann).

\section{Odpowiedzialność za gatunki}

Jak podkreśla Spaemann, nasz obowiązek wobec roślin i zwierząt odnosi się do istnienia gatunków, a nie jednostek. Znaczy to, że możemy zabijać (bacząc przy tym oczywiście na sposób, w jaki to czynimy) poszczególne egzemplarze spośród tych istot, ale nie wolno nam niszczyć całych gatunków. Dlaczego? Różnorodność gatunków objawia nie tylko bogactwo, piękno i dobro tego świata, wspaniałość ich Kreatora, ale stanowi także nieodzowny warunek globalnej, ekologicznej równowagi $^{11}$.

Niestety współczesne metody stosowane w rolnictwie pozbawiły egzystencji ogromną liczbę zwierząt i spowodowały wyginięcie bardzo wielu gatunków. Zjawisko to musi bardzo niepokoić i martwić. Wprawdzie w przeszłości gatunki również wymierały, lecz w dużo wolniejszym tempie i nie w tak znacznych rozmiarach. W dobie obecnej jednak praktycznie każdego roku znika znaczna ich część, a z istniejących zagrożona jest szczególnie egzystencja np. tygrysów w Chinach, ryb oraz ptaków (wywiad, luty 2011). Jakże bardzo ten fakt obciąża su-

11 Jak podkreśla również F. Krenzer, różnorodność gatunków zwierzęcych i roślinnych jest odblaskiem wspaniałości Boga (Krenzer 2000: 262-263). 
mienie współczesnej ludzkości. Nie inaczej się on jawi niż grzech wobec przyszłych pokoleń, którego nic nie może usprawiedliwić. Owszem, nie spoczywa na nas obowiązek planowania ich szczęścia. Wszak powinniśmy przekazać im naturalne bogactwo rzeczywistości w niepomniejszonym zakresie, skoro przez całe życie korzystaliśmy z jego owoców. Cywilizacja, która nie stara się sprostać temu imperatywowi, upodabnia się do świata pasożytów i skazuje na to, że podzieli jego los. Z powodu swej pasożytniczej egzystencji doprowadzi do samozagłady również samą siebie. Wolno zatem wysunąć przeciw takiej cywilizacji silny argument o charakterze utylitarystycznym. Uwzględnia on następstwa lekceważącego odniesienia tej cywilizacji (jej samozniszczenie) względem późniejszych generacji, ponieważ trwoni dobro zawarte w naturze (Spaemann 2000: 473).

\section{Cierpienie zwierząt a kwestia odpowiedzialności}

Według znawców zagadnienia wrażliwość na ból i cierpienie zwierząt to szczególnie paląca kwestia z zakresu problematyki tych istot. Tymczasem również we współczesnej filozofii wskazać można myślicieli stawiających pod znakiem zapytania tego rodzaju przymiot świata zwierzęcego ${ }^{12}$. Oczywiście, stanowisko tych myślicieli uznać trzeba za osobliwe i budzące zdziwienie. Trzeba być raczej, jak podkreśla Spaemann, ślepcem, aby nie dostrzegać, że zwierzę cierpi. Niemieckie prawo stwierdza dlatego: „Nikomu bez rozsądnej przyczyny nie wolno zadawać zwierzęciu bólu, cierpienia lub krzywdy”. Niestety, istnieje zbyt dużo bólu i cierpienia w świecie zwierzęcym z czterech co najmniej powodów: metod hodowli i warunków bytowania sprzecznych z naturą zwierząt, problematycznych eksperymentów (zwłaszcza, gdy pierwszorzędny ich cel dotyczy interesów ekonomicznych i badawczych, a nie dobra zwierząt), uboju. Osobno trzeba podkreślić fakt ingerencji w naturę, tj. manipulacji genetycznych. Oznacza on bowiem, że zwierzę hodowane jest nie dlatego, aby żyło, lecz wyłącznie w celach laboratoryjnych. Tymczasem są to najgorsze $z$ ingerencji, jako że zwie-

12 Wśród filozofów kwestionuących zdolność do doznawania bólu przez zwierzęta autorzy artykułu wymieniają A. Dennetta (2005) Harrisona (1991). 
rzę doznaje cierpienia nie w wyniku choroby lub bólu zadanego z zewnątrz. Zostaje ono na nie skazane na mocy naturalnego uposażenia, z jakim przyszło na świat (Spaemann 1993: 230; wywiad, luty 2011). Ingerencje te są odarte ze wstydliwości. Brakuje im tego, co od czasów greckich było synonimem moralności: wstydu, bojaźni, aidos (Spaemann 1993: 230).

Jak już stwierdzono, zadawanie bólu i cierpienia istocie nań wrażliwej, jaką jest zwierzę, wymaga usprawiedliwienia (podania rozumnej przyczyny). Ból zawiera w sobie apel, by go unikać (Spaemann 1979: 9). Z następującej jeszcze racji nie powinno się nań narażać zwierzęta, zwłaszcza, gdy rodzi wielkie cierpienie. Otóż, jak akcentuje Spaemann, nie potrafią one włączyć swego cierpienia w wyższą tożsamość świadomego kontekstu (czyli nadać mu sensu) i dzięki temu zapanować nad nim. W rezultacie są na nie bez reszty wydane. W ten sposób przeżywane cierpienie staje się dla nich czymś szczególnie dotkliwym, ponieważ w bólu są tylko, by tak rzec, bólem, zwłaszcza wówczas, gdy nie mogą zareagować nań agresją lub ucieczką (Spaemann 2000: 472).

Tymczasem człowiek na różne sposoby przeżywa cierpienie; potrafi potraktować je jako coś zobowiązującego. Z wdzięcznością odnosi się do czasu, w którym zostało mu zaoszczędzone. Jednocześnie, będąc osobą wierzącą, gotów jest je przyjąć z dłoni Bożej, by w ten sposób złączyć się z cierpieniem Chrystusa. Również niewierzący bardziej lub mniej dzielnie stawia mu czoło. Tymczasem zwierzę po prostu cierpi, gdyż nie zauważa celu swych udręk (wywiad, luty 2011).

Z problematyką cierpienia zwierząt ściśle się łączy kwestia odpowiedzialności. Rozróżnić trzeba dwa jej rodzaje, tzn. odpowiedzialność wobec tych jestestw i odpowiedzialność za nie.

\subsection{Cierpienie i odpowiedzialność wobec zwierząt. Problem ich dręczenia}

Nie dotyczy nas odpowiedzialność wobec tych istot żyjących. Jesteśmy bowiem ją winni tylko temu, kto jest w stanie zapytać w formie „dlaczego?” i „na podstawie jakiego prawa” czy też „dla kogo?” coś może być dobre lub złe. Tymczasem nie jesteśmy w stanie dać zwie- 
rzętom możliwości rozstrzygania w tej materii . Perswazja w rodzaju: to cierpienie jest konieczne i należy się na nie zgodzić, a to zbyt duże i nie można, albo nie wolno nam go zadać, nie ma żadnej racji bytu. Zwierzę nie potrafi wyrokować o tym, co jest sprawiedliwe, a co nim nie jest; nie jest przecież obdarzone zmysłem sprawiedliwości. Z tego właśnie powodu nie obowiązuje nas odpowiedzialność przed nim. Zaciągamy ją natomiast wobec Boga, przed którym musimy dokonać rozrachunku z postawy, jaką zajmowaliśmy w stosunku do stworzeń niższego rodzaju.

Trzeba tutaj też podkreślić skutki, jakie może pozostawić po sobie w odniesieniu do innych ludzi, nasz stosunek do zwierząt pozbawiony odpowiedzialności, a przejawiający się dręczeniem tych istot. Jak wspomina Spaemann, już w okresie dzieciństwa wiedział on z katechizmu, że nie można bezzasadnie zadawać zwierzętom cierpienia. W świetle bowiem nauki katolickiej ten, kto surowo obchodzi się ze zwierzętami, również niewłaściwie odnosi się do ludzi lub inaczej mówiąc, stajemy się gorszymi w stosunku do człowieka, jeżeli źle traktujemy zwierzę. Dlaczego występuje ta prawidłowość? Nie zachodziła by ona, gdyby zwierzęta i ludzie nie byli wzajemnie ze sobą spokrewnieni. Jednak faktycznie są nimi. Dlatego prawidłowość ta występuje. Naturalnie, należy zaznaczyć, że nie zachodzi pod tym względem ścisła współzależność. Są ludzie pełni respektu wobec swych bliźnich, a jednocześnie objawiają brak respektu w stosunku do zwierząt. Zdarza się zresztą sytuacja odwrotnego rodzaju, by przywołać chociażby Hitlera, który był miłośnikiem zwierząt. Tak czy inaczej, jak konkluduje Spaemann, w doktrynie Kościoła dręczenie zwierząt zawsze źle było widziane (wywiad, marzec 2011).

\subsection{Cierpienie i odpowiedzialność za zwierzęta}

Jak podkreśla Spaemann, nie przed zwierzętami, lecz za nie odpowiadamy, co szczególnie uwidacznia się na przykładzie problemu cierpienia. Wszak nie za każdy ból i nie za każde zwierzę ponosimy odpowiedzialność. Jak dalece rozpościera się nasza moc działania (nasze możliwości), tak dalece sięga nasza odpowiedzialność za istoty o na- 
turze zmysłowej. Ponosimy odpowiedzialność przede wszystkim za te zwierzęta, które oswoiliśmy i uzależniliśmy od siebie (Spaemann 1993: 61). Traktowania ich jako zwykłych rzeczy zabrania nam szacunek dla samych siebie i nasze roszczenie, aby postrzegano nas jako istoty wyższe od nich.

W najmniejszym stopniu odpowiadamy za cierpienie zwierząt związane $\mathrm{z}$ ich zabijaniem. Akt pozbawiania życia tych istot jest nieodpowiedzialny tylko wtedy, gdy dokonuje się bez konieczności lub przy braku odpowiedniej racji ${ }^{13}$. Normalnie nie może być czymś niegodziwym z dwóch powodów - zwierzę, podobnie jak każda istota żyjąca z wyłączeniem osób - nie jest absolutnym celem dla siebie. Zniszczenie życia tego rodzaju przynależy do procesów natury; żadne zwierzę nie może się zachować przy życiu, nie niszcząc drugiego życia (Spaemann 1979: 9).

Wbrew temu, co niektórzy twierdzą (powód drugi), jego wnętrze nie integruje życia w kształcie biograficznej jedności ${ }^{14}$. Nie można bowiem powiedzieć, aby ono świadomie realizowało cel życia, dokonywało oceny swych działań ${ }^{15}$. Przeciwnie, żyje z chwili na chwilę i inaczej funkcjonować nie potrafi. Zwierzęciu bowiem nie jest dane przebudzić się do rzeczywistości i do bytu. W rezultacie nie zna przeciwieństwa bytu i niebytu, lecz tylko przeciwieństwo bycia takim oto Sosein i bycia innym. Anderssein czyli zwierzę rozróżnia wyłącznie pomiędzy tym, co przyjemne i nieprzyjemne oraz jakościami, np. zielenią i czerwienią.

13 W przypadku więc, gdy nie możemy zapewnić opieki nad zwierzęciem (psem) wolno go nam uśmiercić.

14 Inaczej mówiąc, zwierzę nie dysponuje odniesieniem do siebie w sensie uświadomienia sobie całości bytowania i powiązania poszczególnych stanów w ponadczasową tożsamość (Spaemann 2000: 472).

15 Według np. szwedzkiego bioetyka Andersa Nordgrena określone zwierzęta, np. myszy, rezusy sa podmiotami życia biograficznego, a nie tylko biologicznego. Z życiem bowiem biograficznym zwiazane sa: historia, działania, relacje (Nordgren 2008: 425). Wszak trudno zgodzić się, aby w życiu tych zwierząt miała miejsce historia. Jest ona przecież świadomym i wolnym działaniem. Zwierzęta najwyżej mają historię rozumianą jako dzieje (ponieważ żyją w czasie), a tym bardziej jej nie kreują. A człowiek ją tworzy, bo świadomie i celowo działa. Tak samo nie samo działanie, lecz świadome działanie można uznać za element biografii. 
Dlatego też odpowiedzialność za zwierzęta odnosi się do „jak” ich życia, a nie do istnienia jako takiego (Spaemann 1993: 231).

W jakim stopniu zapobieganie cierpieniu ludzi może usprawiedliwić zadawanie cierpienia zwierzętom? Kwestia ta jest rzeczywiście wielorako złożona. Istnieją zatem takie stopnie cierpienia zwierzęcia, których nigdy i z żadnego powodu nie powinniśmy zadawać istocie żywej. Aby określić ten stopień, trzeba również wziąć pod uwagę długość bólu w stosunku do długości i sposobu życia zwierzęcia (Spaemann 1993: 231). Jeśli zatem zwierzę zrodzone w klatce lub gdziekolwiek indziej, użyte zostaje tylko do celów eksperymentalnych, po czym wkrótce umiera, znaczy to, że całe jego życie polega właściwie na cierpieniu i doznawaniu bólu. Sytuacja taka nie powinna jednak mieć miejsca, ponieważ życie posiada inny sens, aniżeli doświadczenie samego cierpienia i samych bolesnych przeżyć.

Inaczej rzecz się przedstawia w przypadku, gdy ludzie są dotknięci ciężkim cierpieniem. Wówczas dozwolone stają się eksperymenty na zwierzętach, powodujące cierpienie tych stworzeń.

Również wtedy mogą mieć miejsce bolesne eksperymenty, gdy zmierzają do tego, aby - jak podkreśla Spaemann - uchronić piękne oczy przed cierpieniem (wywiad, luty 2011).

Podobnie, nie każde powiększenie pomyślności życia ludzkiego usprawiedliwia wszelkie bez wyjątku cierpienia zwierząt. W rachubę wchodzi testowanie (przy użyciu środków chemicznych) na oczach zajęcy tzw. kropli piękności, powodujące całkowite zniszczenie receptorów wzroku tych zwierząt. Jest to działanie niemoralne (Spaemann 2000: 469).

\section{Ochrona zwierząt a godność człowieka}

Hasło „ochrona zwierząt jest ochroną człowieka” nie jawi się jako fałszywe, ale powierzchowne. Nie interes własny, lecz szacunek dla samego siebie dyktuje, abyśmy pozwolili zwierzętom żyć - krótko, czy długo - zgodnie z ich specyficzną naturą, bez zadawania wielkich cierpień (Spaemann 2000: 471). Czyż zresztą wzgląd na korzyści, nawet o wydźwięku fundamentalnym w postaci dóbr, jakich zwierzęta do- 
starczają, (np. pożywienia, lekarstw) mógłby ostatecznie motywować do roztoczenia nad nimi opieki? W przypadku takim prawdopodobnie dałoby się usprawiedliwić znaczną redukcję różnorodnych gatunków (Spaemann 1993: 231-232).

Wszak w godności człowieka ma swe źródło, uzdolnienie i dążenie, pozwalające w obcowaniu z rzeczywistością oddać sprawiedliwość jej własnej istocie. W odniesieniu do zwierząt wyrazi się ono w traktowaniu zgodnym z prawdą o nich. Nie pozwoli więc w ten sposób odnosić się do tych istot jak gdyby były one rodzajem dobra o charakterze wyłącznie użytecznym. Naturalnie, możemy również z tego punktu widzenia patrzeć na nie, czyli czerpać z nich korzyści. Nie wolno nam jednak ograniczać się do takiego spojrzenia. Zwierzę kryje w sobie bogactwo niewspółmierne w stosunku do sfery wartości użytecznych. Jak słusznie podkreśla Spaemann, ma ono świat wewnętrzny (Spaemann 2000: 472-473). Przedmiot, np. auto znajdujące się w naszym zasięgu, nie postrzega naszej osoby i nie patrzy na nią. Zwierzę natomiast to czyni.

A zatem, szacunek względem nas samych nakazuje nam odniesienie do zwierząt harmonizujące $\mathrm{z}$ ich naturą $\mathrm{i}$ ją respektujące. Tym samym wyznacza zachowania współbrzmiące $\mathrm{z}$ naszą godnością. Właśnie w niej ma swą podstawę uzdolnienie człowieka do troski i odpowiedzialności za przyrodę, a szczególnie za zwierzęta. Dlatego że człowiek ma godność, wyrażającą się w zdolności do relatywizacji własnego punktu widzenia (czynienia naczelnym przedmiotem troski nie siebie, lecz drugiej istoty) może pomóc i otoczyć swą opieką zwierzęta oraz przyczynić się do realizacji zgodnego z ich istotą istnienia. Lepiej rozumiemy tu głęboki sens biblijnego powiedzenia: „cała przyroda poddana jest jego panowaniu”. Inaczej mówiąc, godność człowieka ujawnia się nie tylko w zaniechaniu ekspansjonistycznej i despotycznej postawy, typowej dla tyrana. Wyraża się przede wszystkim w kontemplacyjnym odniesieniu do świata zwierząt, nacechowanym szacunkiem. Pozwala ono, z jednej strony, dojrzeć wewnętrzne, ontyczne bogactwo tego świata - jego piękno, dobroć (godność bowiem, jak trafnie zauważył Goethe, to zdolność okazywania czci nie tylko temu, co jest ponad nami, ale również istotom niższym od nas), a z drugiej 
doświadczyć radości z powyższego faktu i czerpać z niego upodobanie. Dlatego przeżycie smutku pojawia się w następstwie postrzeżenia zjawisk nie mających reperkusji materialnych. I ma miejsce na samą wiadomość np. o wymieraniu lub wyginięciu kolejnych gatunków zwierzęcych. Pragnąc zaś chronić ich świat ze względu na radość lub smutek oznacza, iż motywuje taką postawę nic innego, jak upodobanie. Jak podkreśla Kant, upodobanie płynące z piękna jest bezinteresownym upodobaniem. Potwierdza się tu, że troskę o ten świat nie można tłumaczyć względami obliczonymi na realizację własnych potrzeb (Spaemann 2000: 471-473; Spaemann 1993: 231-232). Jest raczej tak, że właściwością istoty rozumnej jest to, że może ona mieć interes w czymś, z czego nie ma nic (Spaemann 1993: 231-232).

\section{Bibliografia}

Arystoteles, 1972, O duszy, Warszawa.

Arystoteles, 1995, O rodzeniu się zwierząt, Warszawa.

Czarnecki P., 2008, Dylematy etyczne współczesności, Warszawa.

Gilson E., 1960, Tomizm, Warszawa.

Ingesiep H. W., Baranzke H., 2008, Grundwissen Philosophie. Das Tier, Stuttgart.

Kożuchowski J., 2006, Spór o człowieka we współczesnej filozofii niemieckiej, Pelplin.

Krąpiec M. A., 1996, Byt materialny żyjący. Niektóre aspekty filozofii przyrody, w: Krąpiec M. A., Kamiński S., Zdybicka Z. (red.), „Wprowadzenie do filozofii”, Lublin.

Krenzer F., 2000, Morgen wird man wieder glauber, Limburg.

Nordgren A., 2008, Eksperymenty na zwierzętach a teoria ewolucji, w: Woleński J., Hartman J. (red.), „Wiedza o etyce”, Warszawa-Bielsko-Biała.

Plessner H., 1988, Pytanie o conditio humana, Warszawa.

Spaemann R., 1979, Gut und böse, Freiburg.

Spaemann R., 1993, Glück und Wohlwollen Versuch über Ethik, Stuttgart.

Spaemann R., 2000, Grenzen, Stuttgart.

Spaemann R., 2001, Osoby, Warszawa.

Ślipko T., 2009, Bioetyka, Kraków.

Tomasz z Akwinu, 1975, Suma teologiczna 2 O Bogu, Londyn.

Tomasz z Akwinu, 1985, Suma Teologiczna 13 Prawo, Londyn.

Tomasz z Akwinu, 1998, Kwestie dyskutowane o prawdzie tom II, Kęty.

Tietz S., Wild M., 2006, Denken Tiere?, Information Philosophie, 3.

Vardy P., Grosch P., 1995, Etyka, Poznań. 


\section{SUMMARY}

Article presents concept of moral obligations that man has towards animals proposed by Robert Spaemann. Speamann give reasons for perceiving animal as an object of law. His analyses presents possibilities of solving basic moral questions like for example: experiments on animals, animal husbandry, animal slaughter, hunting, interfering into animal's nature and our responsibility for them. Speamann presents very original argumentation for taking care and responsibility for animals, deriving it from human dignity. 